\title{
Existential Nihilism and Self-delusion in Arthur Miller’s Death of a Salesman
}

\section{Khaleel Ismail*}

Department of English Language, College of Science and Humanities, Prince Sattam Bin Abdulaziz University, Kingdom of Saudi Arabia

*Correspondence author: Ismail K, Department of English Language, College of Science and Humanities, Prince Sattam Bin Abdulaziz University, Kingdom of Saudi Arabia, Tel: +966537493033; E-mail: khaleelextra63@gmail.com

Rec date: April 04, 2018; Acc date: April 27, 2018; Pub date: May 03, 2018

Copyright: (c) 2018 Ismail K. This is an open-access article distributed under the terms of the Creative Commons Attribution License, which permits unrestricted use, distribution, and reproduction in any medium, provided the original author and source are credited.

\begin{abstract}
This paper explores the manifestations of nihilism and self-delusion in Arthur Miller's Death of a Salesman. The paper argues that the feelings of hopelessness and despair experienced by the lead character Willy Loman are as a result of the piling pressures of modernity and the emasculating effects of American capitalism engendered by the two World wars. A direct consequence of these nihilistic feelings in the play manifest in the inability of the Loman family to face the harsh realities of everyday affairs, thereby rendering their lives meaningless. The paper concludes that the suicide of Loman at the end of the play is inevitable because it is the natural outcome of existential nihilism, especially the kind induced by industrial capitalism. In this respect, death, as seen at the end of the play, becomes a natural relief to existential suffering.
\end{abstract}

Keywords: Social; War; Peace; Humanity

\section{Introduction}

According to Abbotson [1] "Arthur Asher Miller was born October, 17, 1915 in New York city, the second child of Augusta Miller and Isidore Miller. His mother was age 22 and his father 30 when Miller was born." A great playwright of his time, Miller included his extended family of aunts, uncles, cousins, nephews and nieces in his plays. This is manifests in the play Death of a Salesman (henceforth D.O.S) with his presentation of Happy and Biff as brothers. In his autobiography, Time bends: A Life, cited in Abbotson, Miller "describes Arts and Social Sciences Journal The play marks a shift between the Aristotelian tragedy with the tragic character being someone of nobility or a respectable member of the society to the downfall of an ordinary member man who is poor and unrecognized. Even his name "Lowman" evokes in us a man who is 'low'. Willy Loman is not of noble birth, neither is he a man of fortune, which is the yardstick for assessing the success or otherwise of people in capitalist system.

\section{Nihilism: The Concept and Philosophy}

The Webster's International Dictionary defines nihilism as "a viewpoint that all traditional beliefs are unfounded and that all existence is consequently senseless and useless: a denial of intrinsic meaning and value in life" [2]. As philosophical doctrine, nihilism is often traced to the works of Ivan Turgenev (Fathers and Sons 1961) and the German philosopher, Friedrich Nietzsche (see Rosli Taliff Dictionary of Literary Terms [3]. Nietzsche alongside other philosophers like Jean Paul Sartre and Albert Camus to mention a few, popularize the concept in the twentieth century. Nietzsche himself defines nihilism as the situation which obtains when "everything is permitted" Glicksberg [2]. In other words of Rosen [4], nihilism is therefore characterized by boredom and hopelessness often resulting in despair. Life in this circumstance becomes baseless and rootless without any solid anchor. Rosen [4] further observes that (this) mood of boredom or hopelessness is the most negative manifestation of nihilism." Further, since nihilism is closely tied to the Nietzschean idea of the 'death of God' it follows that where it happens there will be a spiritual chasm in the life of people seized by its feelings. Consequently, there will be neither spiritual nor any material support to latch on to by these people in their period of anguish and despair. It is compelling to note that the causes of these nihilistic feelings are varied and diverse. However, the most important ones in the twentieth century are the two World wars.

There is no doubt that the two World wars in general, and the Second World War in general in particular have impinged on the lives of people in general and that of writers in particular. The war and its attendant consequences of human loss, carnage, senseless violence, and displacement have helped in creating a feeling of alienation and despair among the post-war generations of writers in both Europe and America. As a result of this, their vision and image of man as the paragon of progress and civilization was shaken. The war also left a deep scar on their conscience and at the same time pushed them to question and re-evaluate the much touted humanity of man. Consequently, these writers, through their imagination, seized the initiative to educate people the populace about the existential uncertainties plaguing man in this period of despair and hopelessness. As a natural corollary the characters that peopled their works become the embodiments of these vexatious sentiments. Certainly, one of the post-war plays that mirror these feelings is Arthur Miller's Death of a Salesman [5].

\section{Existentialism: A Modern Philosophy}

Existentialism on the other hand is a philosophical movement whose origin could be traced to the nineteenth century Danish theologian Soren Kierkegaard. It is a very complex philosophy that harbors contradictory and competing ideas. There are two major strands of Existentialism current in the nineteenth century: Christian Existentialism and the Sartrean Existentialism. Whereas the former was built on the Christian morality of the doctrine "the original sin" 
that sees man as doomed to perdition unless redeemed through Christian salvation, the latter is secular and urges people to scorn what they see as "the slave morality of Chistianity" [6]. This paper is however concerned with the Sartrean Existentialism. The Sartrean Existentialists were deeply influenced by the philosophy of the Enlightenment philosopher René Descartes which stresses the centrality of human rationality. This philosophy is anchored on a Cartesian premise that emphasises human existence rather than human essence. This fact is captured in the famous Cartesian declaration, "I think, therefore, I am". Indeed, Sartrean Existentialism is redemptive in that it places collective and individual salvation squarely on the shoulders of the human person. Furthermore, it severely discounted the chances of chance, fate, or god in the existential emancipation and progress of the human person. In addition, this philosophy believes that man can make or mar his future because of his freedom to choose out of the alternatives and competing possibilities. A closer examination of this freedom would reveal its vagueness because these choices are often severely circumscribed and limited. In essence these choices are hollow because they are ultimately controlled by the dominant ideology operational in every society. Consequently, this freedom becomes a "burden...and a source of ...anxiety" for people [3]. This can be seen in Death of a Salesman where despite serious reservations on his part, Loman remains stuck to being a salesman because there is no viable alternative for him at the age of sixty three.

Many scholars have studied the play from different perspectives depending on their interest. For instance, some Marxist scholars such as Raymond Williams have regarded the play as a critique of American capitalism, a system "that brutalises the unsuccessful" [7]. In the view of Feminist critics such as Catherine Belsey, the play "presents a grammar of space that marginalises Linda Loman and all women, who seemed othered, banished to the periphery of a patriarchal world". In view of these scholars, the play portrays women as weak, docile, and subordinated to the patriarchal "Laws of the Father." One useful insight of this observation is the fact that it reinforces the entrenched gender stereotypes operational in Western societies at the time. Central to this is the view that women are discursively constituted as mere appendages to men. Throughout the play, Linda is playing a supporting role.

Benjamin on their part praised Miller for "his understanding and compassion for human beings in their most personal relationshipswith the members of their families or with themselves". Indeed, the play is an attempt to dissect and understand the dynamics that hold relationships in place of post-war American urban society tethering on the brink of disintegration due to the pressures of modernity. It is indeed a condemnation and indictment of American capitalist system. The play reflects the life of a "restless, tormented, impotent individuals who are unable to fasten on a satisfying self-image" [8].

\section{Self-Delusion in Death of a Salesman}

Death of a Salesman is a play that was written four years after the end of the Second World War. The play attempts to mirror the social fragmentation and disintegration of the American family brought about by the two World Wars, the depression, and the holocaust. At the time it was written, the American society was still struggling to overcome the effects of the war. The American economy in particular suffered serious setback as a result of the war and the emergent depression. Ordinary American citizens were made to work harder in order to meet their financial obligations. Consequently, the period becomes characterised by intense competition in all spheres of life. The competition was however, more severe in the commercial are of salesmanship. It is important to note that the salesman a very important person in the American capitalist system. He is the vital link between the producers and the consumers. In this respect, he performs the dual functions of bringing vital goods and services to the consumers as well as accruing benefits to the corporations in terms of profit and sales. The play centres on Willy Loman, a failed salesman whose sons Biff and Happy are also failures largely due to their father's bad influence. Thus, the play is a good illustration of a skewed American dream. This is because at the end of the play the dreams and hopes of the entire Loman family turn out to be a nightmare. Willy Loman is a sixty-three year old man who having spent thirty six of it as a salesman with the Wagners, is removed from salary and placed on a commission, a sign that he is no longer valuable to the company. In the play we are given a picture of a Willy Loman that is despondent and confused. This confusion could be seen right from the beginning of the play. Willy becomes a salesman by chance rather than by choice. This fact can be seen in his confession, thus "When I was a boy, eighteen, nineteen-there was a question in my mind as to whether selling had a future for me". (D.O.S: 58). It stands to reason that even at this early stage Willy Loman did not have a priorities right. His alienation has prevented him from taking the right decision about a vital part of his existence. Hence instead of rationalising his decision based on pragmatism, he chooses to trust his instincts, and by so doing launches himself on a dangerous and irreversible course of action that will eventually leads to his destruction.

In the text, Loman is a nihilist whose idealistic dream of success turns out to be an illusion. Rosen posits that "nihilism arises not from the absence of truth, but its tedious presence" [4]. This is indeed very true as shown in the Death of a Salesman where in spite of expressed misgivings about salesmanship, Loman still clings to it against all hope because he is immersed in the illusionistic dream of a non-existent success. Stambusky believes that in the text, Miller "illustrates how a good man can be destroyed by the 'wrong dream' of a shallow, materialistic way of life based on false ideas" [9].

It is worth to note that throughout the Death of a Salesman, Willy Loman is characterised by lies, falsehood and self-delusion. Example of his lies is at the beginning of the play when he comes back home. His wife Linda asks of his car and he remarks "Chevrolet, Linda, is the greatest car ever built." (D.O.S: 20). But just some minutes later, when she reminds him to pay Frank who repairs the car's carburettor, he says angrily, "...That goddamn Chevrolet, they ought to prohibit the manufacture of that car!" (D.O.S: 22)His fault idealism creates a gap between him and the people he comes into contact with. For example, throughout the text, he made several attempts, despite protestations to the contrary, to imbue his eldest son, Biff Loman with a false aura of greatness. His command to Biff is always, "Be liked and you will never want. You take me, for instance. I never have to wait in line to see a buyer. 'Willy Loman is here!' That's all they have to know, and I go right through." (D.O.S: 20). However, these efforts draw nothing from Biff but scorn. As a matter of fact, Willy finds it increasingly difficult to cultivate and maintain personal relationship because he is too sensitive to failures. He lives in the shadow of this failure throughout the play. For example, he is nervous in the presence of Biff because he (Biff) can see through his fakeness. Hence, despite his spirited attempts to get closer to Biff, a wide gulp practically exists between them, and this gap continues to widen throughout the play. Unlike his father, Biff made several attempts to escape from the fantasy of the Loman family. He despises his father's false hopes and belief about the greatness of the 
family. In the heat of argument with Loman, he admits that the whole family never told the truth for ten minutes. His words are: "We never told the truth for ten minutes in this house". (D.O.S: 100). This revelation is made where, after several attempts to find a steady employment for himself fails. Loman has in a moment of desperation encourages Biff to go to Bill Oliver (Biff's former employer) and solicit for loan to start a cattle business. In spite of his reservations about the suggestion, Bill obeys his father. He is however unsuccessful in securing the loan because Bill could not even remember knowing him. It is after this encounters that he comes to the realization that his life has been shackled by a maniacal desire to please his father at all cost. He therefore resolves from then on to free himself from the restraints placed on him by his father. In the text he rhetorically asked, "Why am I trying to become what I don't want to be? What am I doing in an office, making a contemptuous, begging fool of myself, when all I want is out there, waiting for the moment I say I know who I am". (D.O.S: 104). He is the first to admit that Loman is a "phony little fake".

However, Happy is a self-deluded type who takes after his father. He is the metaphor of failure and an embodiment of false hopes like Willy. Happy is completely submerged into what Williams calls "the conditioned attitudes in which Loman trains his sons" [10]. These attitudes could be surmised to be the lies about successes and achievements that are the normal diet of the Loman family. He is totally blinded by the empty talks of his father. Like his father, Happy believes that all what it takes to succeed in life is the right personality rather than hard work. He thus becomes lazy, lethargic and hedonistic. His index of success in the play is measured by the number of women he "knocked down". According to Judah Bierman et al. "Happy is a philanderer (that) wastes himself in a succession of casual fruitless union (with women)" [11]. But in spite of his closeness to his father, Happy has the audacity to declare that Loman is not his father. Thus, when Happy's new girlfriend Letta refers to Loman as his father at a chance meeting in a restaurant, he quickly denounces him saying that he (Loman) is just a guy. He says to Letta, "No, that's not my father. He is just a guy" (D.O.S: 87 )

Willy Loman's self-delusion made it nearly impossible to establish a cordial relationship with his close door neighbour, Charley. In contrast to Loman, Charley is practically a successful business man. In the text, he severally offers to help Loman with a job but always meets steep resistance. This is up to the time when Loman is fired from his job. Willy's reply always is "I-I just can't work for you" (D.O.S: 73). As a matter of fact, Loman is jealous of Charley because both he and his son Bernard (a lawyer) are successful. Even so, Charley continues to be a friend to Loman, often times cautioning him in his over-enthusiasm about life. He keeps lending Loman money even though he knows the latter cannot pay back.

Another important character suffering from self-delusion is Linda, Loman's wife. In her enthusiasm to please her husband, she becomes blinded to the reality of their life. She exudes confidence in her husband and takes his words at face value. She only comes to grasp the reality of their life after his death. For example, her faith in the worth of him is betrayed during his funeral. Taking his words that he is well loved all over the territory, she expects people to turn out in their multitudes to honor him. Paradoxically, only four of them (herself, Biff, Happy and Charley) attend the funeral. At this turn of event, she asks, "Why didn't anyone come" (D.O.S: 106). Biff replies to her that "He had the wrong dreams. All, all, wrong". (D.O.S 107).

Death of a Salesman concludes with the death of Loman through suicide. With his death in this manner, the nihilistic cycle in the play is complete. According to Glicksberg when "nihilism takes over, (the life of a person), the victim of suffering comes to realise there is no justification for his suffering" [2]. The victim will consequently seek to end his suffering through suicide. Glicksberg (ibid) goes on to say that "the logical outcome of nihilism is suicide" [2].

\section{Conclusion}

It is pertinently clear from the life of Willy Loman that he is spiderwebbed by self-delusion which ultimately spills to his family. $\mathrm{He}$ constructs a false identity for himself and his sons, Biff and Happy. Throughout the play, Loman is presented as a pathetic figure with the wrong dreams of greatness and success. He fails to adjust himself to the realities of his world and his existence. He rather chose to live inside the relative safety of an imagined "comfortable" life. This eventually leads to his nihilistic destruction at the end of the play.

\section{References}

1. Abbotson S (2007) Critical Companion to Arthur Miller. New York: VB Hermitage.

2. Charles IG (1975) The Literature of Nihilism. London: Associated Press.

3. Rosli T (2000) Dictionary of Literary Terms. Malaysia: Pearson Education Asia.

4. Rosen S (1969) Nihilism: A philosophical Essay. New Haven: Yale Press.

5. Miller (1949) A Death of a Salesman. London: Educational Books Ltd.

6. Cruikshank J (1962) French Literature and Its Background. Oxford: Oxford University Press, 6: 184.

7. Bigsby C (1997) The Cambridge Companion to Arthur Miller. Cambridge: The University Press 41(3): 504-506.

8. Tindall B (1989) America, New York: W.W. Norton \& Co.

9. Stambusky A (1968) Arthur Miller: Aristotelian Canons in Twentieth Century Drama. Modern American Drama: Essays in Criticism. Florida: De Lande.

10. Williams R (1952) Drama from Ibsen to Brecht. New York: Chatto and Windus.

11. Campbell J (2001) Death of a Salesman. New Delhi: Rama Brothers Educational Publishers. 